\title{
"A Is A": Spider-Man, Ayn Rand, and What Man Ought to Be
}

\author{
Claudia Franziska Brühwiler, University of St. Gallen
}

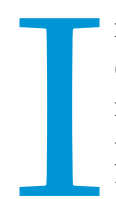

n 1979, writer Tom DeFalco was paired with artist and cocreator of Spider-Man, Steve Ditko, to work on an issue of Machine Man, one of the many superheroes populating the universe of Marvel Comics. Instead of the usual introduction and business chatter, Ditko challenged DeFalco during a first conversation: "Are you Tom? What gives you the right to write about heroes?" (Tucker 2012). By the time of this exchange, Ditko had not only (co-) created and continued numerous superhero stories, ranging from Captain Atom to Dr. Strange or the Hulk, but he had also dedicated a lot of thought to the question as to what composed true heroism. In the 196os, he had already found answers in a place not uncommon for that time, namely, in the novels of a Russian immigrant whose work should serve, in her own words, as "the projection of an ideal man" (Rand 1943, ix; 1975, 162; 2005, 230): Ayn Rand (1905-1982).

Born in prerevolutionary St. Petersburg in 1905, the woman once known as Alisa Rosenbaum had to leave her home country because of desolate economic circumstances and ideological inhibitions that put an outspoken individual like herself at risk. ${ }^{1}$ Upon her departure, she promised her parents to become famous abroad, and indeed she would. After a shaky start as a screenwriter at Cecil B. DeMille's studios, she published her début novel We the Living in 1936 wherein she showed the bleak reality of life under Russia's new regime. It was, however, the tale of an architect who defied the usual conventions of his trade and stayed true to his visions that brought about Rand's literary breakthrough in 1943. The Fountainhead and its protagonist Howard Roark stood for a stark individualism, celebrating a relentless independence from societal demands and expectations. Together with her 1957 magnum opus Atlas Shrugged, the novel encapsulates Rand's core beliefs, which she later framed as her philosophy, objectivism. The core tenets of objectivism consist in a belief in objective reality that man can perceive thanks to reason and in the advocacy of rational self-interest that, on a political level, depends on a capitalist system (Rand 1957).

Steve Ditko became acquainted with Ayn Rand's work in the early 196os, apparently by recommendation of SpiderMan's cocreator and Marvel's editor-in-chief Stan Lee (Bell 2008). Rand's ideas would leave their imprint on both SpiderMan and Ditko's later work. Beyond this immediate impact, Ditko's Randian creations would inspire other comic authors and thus extend their ideological reach. Rand's influence on Ditko and those drawn to his work exemplifies, on the one hand, the way political ideas can shape the superhero genre and have a profound impact on art and the artist. On the other hand, it is just as telling of how ideas are reinterpreted by artists and readers and thereby become more palpable through comics as a medium.

\section{THE RISE OF THE OBJECTIVIST HERO: FROM SPIDER-MAN TO MR. A}

In Spider-Man \#38 (1966), a student protest is taking place on the grounds of Peter Parker's-aka Spider-Man's-college. Prompted to join their cause, Peter meets his peers' request with disdain, and the brief exchange reveals the true motivations of the protesters, namely, their laziness and their longing for quick fame and idle fun:

\footnotetext{
"Hey, Parker! Not so fast! We can use another man to carry a sign! C'mon, join the protest march!"

[Peter Parker:] "Not me! I haven't got enough time! Besides, I've got nothing to protest about!"

"Nothing to protest about?? What are you-some kinda religious fanatic, or somethin'?"

"What 'smatter with you? Aren't you interested in saving the world? Anyway, it's an excuse to cut classes!"

“-and maybe you'll get your picture in Newsweek!" (Lee and Ditko 1966, 157)
}

Cold, arrogant, detached from the lives of others, but driven to follow his purpose and pursue higher ends, that is the Peter Parker of this episode that stands at the end of the four-yearlong cooperation between author Stan Lee and artist Steve Ditko on their joint creation, Spider-Man. This particular scene is often quoted as an example of how the discovery of Ayn Rand's works changed Steve Ditko and thus Spider-Man, and ultimately drove a wedge between author and artist (Bell 2008; DiPaolo 2011). Rand's disgust for the hippies of the 1960s, the student protesters, and the "moochers" who wanted to live off the state is mirrored in the Peter Parker who came to resemble Howard Roark, the protagonist of The Fountainhead (Genter 2007). At the same time, Ditko developed a strong sense of intellectual property and became less tolerant of Stan Lee's claims on Spider-Man (Bell 2008; Howe 2012; Morrison 2012), and he demanded to be recognized as his cocreator and the one who, by 1965, actually developed the plots. A few issues after the student protest scene, however, a short-lived truce between the two strong figures ended, and Ditko started working for other comic book publishers-and he went on his mission to create the perfect Randian hero.

Such a Randian hero would have to withstand challenges as Ditko described them in his independent comic The Avenging World (1973). Therein, the world needs to take revenge against figures like the "mystic," the "skeptical intellectual" who asserts that "a truth can be a lie" or that "the irrational 
works" (ibid., 2), or against the "neutralist" who refuses to take a stand for anything. A grumpy looking planet earth, the eponymous "avenging world," warns humanity of the collective good fallacy and compromises: "You can't have it both ways! You must choose between Good and Evil ... Life and Death!" (18).

In 1967, Ditko made his first attempt at a Randian hero, creating The Question for Charlton Comics. In his public life, The Question is an investigative journalist, who is able to turn into a featureless avenger thanks to artificial skin. Thus clad, he announces his appearance with a card on which a question mark flashes up, and demands the target person to choose sides. He is leaving more room for explanations than Ditko's next Randian hero. Mr. A (1969-1973) would not raise questions, but seek clear-cut answers. Mr. A also marks his appearance with a card; his, however, is half black, half white. As he explains to the evildoers he catches, "it's either or" (11): "Those who attempt to create a fake world by evading the truth only succeed in making themselves a slave to an unreal and a fake in the real world!" (ibid.)

Mr. A is the quintessential Randian protagonist. By day, Rex Greiner is also a journalist in pursuit of truth and justice, but when he cannot reach these goals by the pen, he puts on his iron gloves and a steel mask to go after evil. In this mission, he takes no prisoners and leaves his opponents neither life nor dignity, claiming the right to kill sources of evil:

A man can only live HIS OWN life. When he refuses to know what is TRUE or FALSE, he is refusing to support and defend his life. When he ACTS on what he knows is true, he acts for his SURVIVAL. When he EVADES or ACTS in what he KNOWS is false, he acts toward his SELF-DESTRUCTION. A man's actions are life-serving or death serving. MAKE YOUR CHOICE! (24)

The themes he addresses in his frequent monologues echo Ayn Rand, specifically, her ethics of rational self-interest, her idolization of human rationality, and her disdain for relativism and altruism. ${ }^{2}$ Interestingly, Ditko also adopted Ayn Rand's aesthetic theory when he shares his reading of Aristotle's Poetics: "Aristotle said that art is philosophically more important than history. History tells how man did act-art shows how man could and should act" (Bell 2008, 111). Thereby, he practically parrots Rand's words according to which Aristotle argued that "fiction was more important than history" since fiction presents things "as they might be and ought to be" (Podritske and Schwarzt 2009, 128-129). As would become palpable in Ditko's work as well, Rand derives a "basic principle" from Aristotle's Poetics, namely, that "the role of a fiction writer is to present things, not as they are, but as they might be and ought to be" (Rand 1975, 95). Ditko followed this principle by creating the ideal objectivist hero.

Ayn Rand's interpretation of Aristotle's comparison of literature and history does not hold, however, if one turns to the original passage in Poetics wherein he states that the "true difference is that [history] relates what has happened, [poetry] what may happen. Poetry, therefore, is a more philosophical and a higher thing than history: for poetry tends to express the universal, history the particular" (chpt. IX). Rand was cor- rect to see that Aristotle held poetry in high esteem, yet not only for its ability to develop counterhistories, but also for its universality. Moreover, he did not urge writers to strive to project an ideal world or man, as Rand had interpreted his words. ${ }^{3}$ Instead, Aristotle simply implied this possibility, without making any normative claims. As a consequence, other readers of his statements suggested that literature could surprise us not only with the creation of ideal worlds, but also with the very opposite.

By following Rand's vision of art and her ideal of the rational being, Ditko voluntarily constrained his imagination of counterworlds and counterheroes. In his case, however, others picked up his ideas and creations to show what other lives a Randian hero may lead, as examples by Alan Moore and Frank Miller show.

\section{AN HEIR TO DITKO'S CREATIONS: QUIS CUSTODIET CUSTODES?}

He had one room above a thrift store. / He had a trunk of books by Ayn Rand. / He was short-sighted and reclusive, / Resisting pleas to take his photograph.

He drew a super-hero comic. / He saw the world in terms of black and white. / He said, "A day's work for a day's pay, / That is our one and only right."

Thus quoted Alan Moore from the song "Mr. A," part of the repertoire of his band The Emperors of Ice Cream, in an interview with BBC 4's Jonathan Ross (2007). The lyrics convey a great familiarity with Ditko's life, work, and ideology, bowing to the artist but taking an ironic distance from the objectivist. Moore dryly illustrates how objectivism shaped not only Ditko's artistry, but also his life as he turned into a recluse without the faintest interest in cashing in on his SpiderMan fame. This ambiguous attitude vis-à-vis another great comic artist and author becomes even more evident in Alan Moore's own major creation, the groundbreaking graphic novel Watchmen (1987), for which artist David Gibbons gave the decisive impulse.

When Charlton Comics went bankrupt in 1985 , Gibbons seized the opportunity to suggest the integration of former Charlton characters into a new work (Morrison 2012) that revolves around the repeatedly quoted question quis custodiet custodies-who watches the watchmen, the caped avengers and the government that employs them at times. The line-up of Charlton Comics characters included three creations of Ditko, among them The Question. In the hands of Gibbons and Moore, Ditko's first attempt at an objectivist hero bears the marks of a traumatic past on his disfigured face, which is hidden underneath an ink-blotted mask, in reference to the test that gives him his name, Rorschach. Hughes (2006) rightly points out how the mask exemplifies Rorschach's black-and-white worldview, his perception of right and wrong, good and evil, and what Morrison (2012) called his "dogged determination and clarity of purpose" (198). "Because there is Good and there is Evil, and Evil must be punished. Even in the face of Armageddon I shall not compromise in this [,]" thus Rorschach's creed (Moore and Gibbons 1987, chpt. 1, 24). 
Yet Hughes's observation can be taken further. The repeatedly changing inkblot mask does not only reflect Rorschach's ideological outlook, but it can simultaneously be read as a criticism of this dichotomous approach to reality. Although a Rorschach test itself is composed of black and white shapes, it does not unveil a clear-cut world. Just as the ink may blur at its edges, the associations it evokes blur different visions of reality and are open to multiple interpretations, as the episode of Rorschach's-or Walter Joseph Kovacs's, as goes his actual name-own inkblot test conveys (Moore and Gibbons 1987, chpt. 6, 1-5 and 17-26). Rorschach humors a psychoanalyst by seeing butterflies when he actually thinks of a horrid murder case, flowers where he actually remembers a childhood trauma. Unwittingly, his act, that is, cheating at a supposedly reliable test, points out the many layers of reality. Moore and Gibbons thus already incorporate their critique of Rorschach's-and Ditko's Randian-worldview in the choice of his guise. A Manichean worldview, in which we are limited to an either/or decision and need to compartmentalize people into two categories, ignores the actual complexity of human relations and values. Rorschach as a character himself is already proof thereof, when, for instance, he doggedly pursues to punish the murderer of a masked avenger who was guilty of various crimes. In the course of the plot, we become aware of the relativity of values and reality as well as of Rorschach's limited worldview. Ultimately, Rorschach becomes exemplary of how comics can critically reflect on ideologies: not by text alone, but also by visual clues, such as a slightly changed guise of a known comic hero, and by entering into a dialogue with prior works, that is, by creating an intertext.

\section{RAND'S APPEAL TO COMIC ARTISTS BEYOND DITKO}

While Alan Moore's take on The Question was evidently not free of irony, he was by no means the only comic author who drew from Ayn Rand's theories, be it to mock them or to share and celebrate them. Apart from a comic biography (Blundell and Tennant 2011) and the rather less appealing comic version of the 1938 novella Anthem (Santino and Staton 2011), it is probably Frank Miller who has most openly incorporated Randian elements in his stories-and he even made political statements worthy of a cliché adherent of objectivism. Already one of Miller's most famous graphic novels, Batman: The Dark Knight Returns not only continued the traditional depiction of Bob Kane's caped crusader as the "ultimate capitalist hero" (Morrison 2012, 26), but cast him as a "rugged libertarian" (ibid., 190). Batman's disdain for government and its mercenary Superman as well as for a society that drifted into a mediadriven apathy does indeed echo Rand's dystopian vision of a statist future. Miller would later even name a central group of characters in Sin City (1991-200o) the Roark family, and include Ditko's The Question in Batman: The Dark Knight Strikes Again (2001/2002). It is beyond doubt that Miller is aware of Ditko's vision for The Question, when he lets the latter deliver the following line: "I'm no Ayn Rander! She didn't go nearly far enough!" (Miller and Varley 2002, 74). An actual "creative debt" (Miller and Gibbons 1995, 137) to Ayn Rand only had to be acknowledged, though, for a later Miller creation's adventure, Martha Washington.
An African American, born in 1995, a superb soldier with superhuman tenacity and endurance, Martha Washington Goes to War in the second part of her comic book existence. She owes her name to the fact that she will play a vital role in the second civil war of the United States, and finally lead another revolution against forces that try to subject citizens to a totalitarian regime. Before leading the rebellion, however, she has to undergo an odyssey reminiscent of Dagny Taggard in Atlas Shrugged who attempts to save her company against an ever more intrusive government. Just like Dagny, Martha learns that her side of the conflict is "losing our best and brightest, Washington. [...] They're disappearing on us and we don't know where they're going" (Miller and Gibbons 1998, 41). While the government blames these disappearances on "ghosts," Washington's quest for truth will bring her to a blissful counterworld, a futuristic play on Galt's Gulch, and to the realization that she had been fighting for an unworthy cause and a deceitful government. Miller wrote Martha Washington to honor Ayn Rand, whose work appealed to him for its moral clarity and the type of heroes it celebrated:

Eschewing the easy and much-used totalitarian menace made popular by George Orwell, Rand focused instead on issues of competence and incompetence, courage and cowardice, and took the fate of humanity out of the hands of a convenient "Big Brother" and placed it in the hands of individuals with individual strengths and individual choices made for good or evil (ibid., 137).

In contrast to Steve Ditko, Frank Miller never claimed to be an objectivist, nor does his other work offer compelling evidence to surmise him as the type of Randian underground comic author Harvey Pekar portrayed in Ego \& Hubris (2006), blogger Michael Malice. Still, Miller conveyed the extent of his libertarian ${ }^{4}$ beliefs in a blog rant targeting the Occupy Wall Street movement in November 2011, condemning the protesters as "nothing but a pack of louts, thieves, and rapists, an unruly mob, fed by Woodstock-era nostalgia and putrid false righteousness. These clowns can do nothing but harm America." In a tone that may remind readers of Howard Roark's speech against second-handers or John Galt's disdain for looters, Miller criticized the comfortable class of iPodowning demonstrators, declaring that, "This is no popular uprising. This is garbage. And goodness knows they're spewing their garbage-both politically and physically-every which way they can find" (ibid.). The media backlash against Miller reached even the other side of the Atlantic, with, for instance, the German magazine Spiegel wondering about the comic author's harsh attitude and echoing his colleague Alan Moore's counterattack (Pannor 2011).

It is unlikely that Frank Miller will turn into another Randian crusader like Steve Ditko and forsake commercial profits to dedicate his art solely to ideological causes and to projects that are of value to him alone. His example shows, however, that Rand's influence can be felt in other superhero pieces than just Ditko's creations and that her own projection of the "ideal man" found one of its most striking dedications in the world of masked crusaders. Just open one of the newest additions to the world of Batman, Chip Kidd's and Dave Taylor's 
Death by Design (2012) and see characters pass, plots unfold, and themes explored that will strongly remind you of a certain architect's resistance to convention-including the willingness to see one's work destroyed rather than abused, altered, or in decay. Whether the typical superhero fan will see the parallels, grasp Rand's and Ditko's answer to the nature of heroism, and find it the most compelling is yet a different question.

\section{ACKNOWLEDGMENTS}

I thank Professor Ana Merino, PhD, from the University of Iowa for giving me a more profound understanding of the world of comics and superheroes. I am likewise indebted to symposium editors Matt Costello and Kent Worcester for their valuable suggestions and comments.

\section{NOTES}

1. A more detailed account of Ayn Rand's early life in Russia is provided by Burns (2009, 9-19) and Heller (2009, 1-51). The earliest official Rand biography was written by her former acolytes Nathaniel and Barbara Branden (1962/1968). Both later published their memories of the time with Ayn Rand. While her ex-husband and formerly proclaimed intellectual heir to Rand, Nathaniel Branden, focused mainly on his own relationship with the thinker (1989/1999), Barbara Branden (1986) covered her idol's early life as well.

2. Incidentally, Ditko also uses a stylistic device that reminds us of Rand: frequent monologues. The Avenging World is in fact mainly a long monologue by the title-giving character, the world, interspersed with statements and little scenes to underline an argument.

3. On this point, see Torres and Marder Kamhi (2000, 63-64) and Cox (1986, 23) who have also commented on Rand's interpretation of Aristotle.

4. For some, his outburst gave rise again to allegations of fascism. Moody (2011) provides an overview why Miller should be considered a cryptofascist. Interestingly, this verdict was not shared by the press in Germanspeaking Europe. Reviewing the German translation of Holy Terror (2011), Miller's reaction to September 11, several critics felt that, though it was an overly patriotic work of an obviously right-leaning artist, they could not accuse Miller of fascist ideas (see Honert 2012; Kreitling 2011; Schlüter 2011).

\section{REFERENCES}

Bell, Blake. 2008. Strange and Stranger: The World of Steve Ditko. Seattle, WA: Fantagraphic Books.

Blundell, John (w), and Todd Tennant (a). 2011. "Ayn Rand." Female Force May. Vancouver, WA: Bluewater Productions.

Branden, Barbara. 1986. The Passion of Ayn Rand. New York: Anchor Books.

Branden, Barbara, and Nathaniel Branden. 1962/1968. Who Is Ayn Rand? New York: Paperback Library, Inc.

Branden, Nathaniel. 1989/1999. My Years with Ayn Rand. San Francisco: JosseyBass Publishers.

Burns, Jennifer. 2009. Goddess of the Market: Ayn Rand and the American Right. Oxford: Oxford University Press.

Cox, Stephen. 1986. “Ayn Rand: Theory versus Creative Life.” The Journal of Libertarian Studies 8 (1): 19-29.

DiPaolo, Marc. 2011. War, Politics and Superheroes: Ethics and Propaganda in Comics and Film. Jefferson, North Carolina and London: McFarland \& Company, Inc.

Ditko, Steve (w \& a).1973. The Avenging World. San Jose, CA: Bruche Hershenson. 1957-1986/2010. The Cover Series. Bellingham, WA: Robin Snyder and Steve Ditko.
. 1969-1973/2010. Mr. A. 2nd ed. Bellingham, WA: Robin Snyder and Steve Ditko.

Genter, Robert. 2007. “'With Great Power Comes Great Responsibility': Cold War Culture and the Birth of Marvel Comics." Journal of Popular Culture $40(6): 953-78$.

Heller, Anne C. 2009. Ayn Rand and the World She Made. New York, London, Toronto, Sydney, Auckland: Nan A. Talese.

Honert, Moritz. 2012. "Ab in die Hölle!" Der Tagesspiegel Online and ZEIT Online November 8. http://www.tagesspiegel.de/kultur/frank-miller-ab-in -die-hoelle/7359566.html.

Howe, Sean. 2012. Marvel Comics: The Untold Story. New York: Harper Collins.

Hughes, Jamie A. 2006. “'Who Watches the Watchmen?': Ideology and 'Real World' Superheroes." The Journal of Popular Culture 39 (4): 546-57.

Kidd, Chip (w), and Dave Taylor (a). 2012. Batman: Death by Design. New York: DC Comics.

Kreitling, Holger. 2011. "Vom Überlebenstrieb der Superhelden.” Die Welt October 5, 22.

Lee, Stan (w), and Steve Ditko (a). 1966/2010. "Just a Guy Named Joe!" The Amazing Spider-Man 38 (July). In Marvel Masterworks: The Amazing Spider Man Vol. 4. 145-67. Salem, VA: Marvel.

Miller, Frank. 2011. "Anarchy.” Blog Nov. 11. http://frankmillerink.com/.

Miller, Frank (w \& p). 1986/2002. Batman: The Dark Knight Returns. With Klaus Janson (i) and Lynn Varley (c). New York: DC Comics.

Miller, Frank (w), and Dave Gibbons (a). 1998/1995. Martha Washington Goes to War. Milwaukie, OR: Dark Horse Comics.

Miller, Frank (a), and Lynn Varley (c). 2002. The Dark Knight Strikes Again. Issue 3. New York: DC Comics.

Moody, Rick. 2011. "Frank Miller and the Rise of Cryptofascist Hollywood." The Guardian November 24. http://www.theguardian.com/culture/2011 /nov/24/frank-miller-hollywood-fascism.

Moore, Alan (w), and Dave Gibbons (a). 1987/2008. Watchmen. New York: DC Comics.

Morrison, Grant. 2012. Supergods: What Masked Vigilantes, Miraculous Militants, and a Sun God from Smalville Can Teach Us about Being Human. New York: Spiegel \& Grau.

Pannor, Stefan. 2011. "Occupy Streit zwischen Comic-Titanen: Alan Moore greift Frank Miller an." Spiegel Online December. 9. http://www.spiegel.de /kultur/gesellschaft/occupy-streit-unter-comic-titanen-alan-moore-greiftfrank-miller-an-a-802826.html.

Pekar, Harvey (w). 2006. Ego \& Hubris: The Michael Malice Story. With Gary Dumm (a). New York: Ballantine Books.

Podritske, Marlene, and Peter Schwartz, eds. 2009. Objectively Speaking: Ayn Rand Interviewed. Lanham, MD: Lexington Books.

Rand, Ayn. 2005. Answers: The Best of Her QEA, ed. R. Mayhew. New York: Signet Books.

2000. The Art of Fiction: A Guide for Writers and Readers. New York: Plume.

. 1957/1996. Atlas Shrugged. New York: Signet Books.

. 1975. The Romantic Manifesto. New York: Signet.

-1943/2007. The Fountainhead. London: Penguin Books.

Ross, Jonathan. 2007. In Search of Steve Ditko. Directed by Peter Boyd Machlean (BBC 4$)$. TV documentary.

Santino, Charles (w), and Joe Staton (a). 2011. Ayn Rand's Anthem. New York: New American Library.

Schlüter, Christian. 2011. "Schlag den Mohammed-Wenn der Islamkritik auch Taten folgen: Frank Millers blutige Rachefantasie 'Holy Terror'." Berliner Zeitung October 14, 24.

Torres, Louis, and Michelle Marder Kamhi. 20oo. What Art Is: The Esthetic Theory of Ayn Rand. Chicago, LaSalle, IL: Open Court.

Tucker, Reed. 2012. “The Secret Hero of Spider-Man.” New York Post July 2. http://www.nypost.com/p/entertainment/the_secret_hero_of_spider_man XHZklFc7QJWuekwj2zDDCM. 